Zeszyty Naukowe Szkoły Głównej Gospodarstwa Wiejskiego

Ekonomika i Organizacja Gospodarki Żywnościowej nr 108, 2014: 133-143

Jan Zawadka

Wydział Nauk Ekonomicznych

Szkoła Główna Gospodarstwa Wiejskiego w Warszawie

\title{
Preferencje i zachowania osób wypoczywających w gospodarstwach agroturystycznych w sąsiedztwie Kampinoskiego Parku Narodowego
}

\section{Wstęp}

Po tym jak transformacja ustrojowa i gospodarcza w Polsce ujawniła nierentowność i nieprzystosowanie rolnictwa do nowego modelu państwa i gospodarki rynkowej, koncepcja rozwoju regionów o charakterze monofunkcyjnym zmierza do zróżnicowania ich gospodarki, a kluczowym problemem związanym z zapewnieniem ludności wiejskiej poprawy standardu życia jest rozwijanie pozarolniczych funkcji obszarów wiejskich [Kłodziński i Rzeczkowska 2000, s. 81]. Model wielofunkcyjnego rozwoju obszarów wiejskich uznawany jest dziś za jedną z podstawowych kategorii polityki względem rolnictwa i obszarów wiejskich w Polsce [Kłodziński 1999, s. 10]. Efektem tego jest fakt, iż rolnictwo dawno już przestało być dominującą funkcją obszarów wiejskich w wielu regionach Polski. Poza wieloma pozarolniczymi kierunkami aktywności gospodarczej mieszkańców obszarów niegdyś ściśle rolniczych coraz częściej dostrzega się społeczne, kulturowe oraz przyrodnicze funkcje wsi.

Jednym z przejawów rozwoju wielofunkcyjnego, który łączy wymienione elementy, jest turystyka wiejska, a w jej obrębie agroturystyka, którą traktuje się jako ważną gałąź aktywności pozarolniczej, nie tylko w skali lokalnej, ale i krajowej. Jej skuteczność wzmaga duża popularność tej formy wypoczynku wśród mieszkańców miast, co intensyfikuje zainteresowanie rolników goszczeniem turystów we własnych domach.

W ciagu ostatnich lat w agroturystyce zaszły znaczące zmiany, które dotyczą głównie jakości i zakresu oferty świadczonych usług. Odpowiednie jej dopasowanie do poszczególnych segmentów rynku wymaga jednak rozpoznania 
potrzeb, preferencji i oczekiwań osób najbardziej zainteresowanych wypoczynkiem na wsi, czyli samych turystów. Tworzenie oferty wypoczynkowej i produktu turystycznego zgodnego z oczekiwaniami wypoczywających zwiększaja szanse oraz wielkość dochodu wiejskich usługodawców na skutek rozwoju funkcji recepcyjnej obszarów wiejskich.

\section{Cele i metody}

W niniejszym opracowaniu zaprezentowano wyniki badań, których celem było rozpoznanie i ukazanie preferencji i zachowań osób wypoczywających w gospodarstwach agroturystycznych funkcjonujących w okolicach Kampinoskiego Parku Narodowego. Badania z wykorzystaniem techniki ankietowej przeprowadzone zostały w okresie letnim 2013 roku na próbie 133 turystów.

\section{Wyniki badań i dyskusja}

Badani turyści byli zróżnicowani pod względem płci i wieku. Kobiety stanowiły $53,4 \%$ badanej grupy. Najliczniejszą grupą były osoby w wieku od 31 do 50 lat $(48,1 \%)$ oraz między 51 . a 65 . rokiem życia $-31,6 \%$. 9,0\% badanej grupy stanowiły osoby młode (do 30. roku życia), a 11,3\% osoby starsze - powyżej 65 lat. Wypoczywający legitymowali się stosunkowo wysokim poziomem wykształcenia. $65,4 \%$ z nich było po studiach, 30,0\% ukończyło szkołę średnią, a $4,5 \%$ deklarowało wykształcenie zasadnicze. $Z$ poziomem wykształcenia powiązany był rodzaj wykonywanej pracy. Szczegóły na ten temat zaprezentowano na rysunku 1.

Znaczny odsetek osób wykonujących prace umysłowe świadczy o potrzebie tej grupy w zakresie wypoczynku w cichym i spokojnym miejscu, z dala od zgiełku i tłumów charakterystycznych dla miejscowości typowo turystycznych.

Respondenci dość pozytywnie oceniali własną sytuację materialną-36,8\% jako dobra, a 42,9\% jako zadowalającą. Sytuację dostateczną deklarowało 12,8\%, a bardzo dobrą i złą odpowiednio 2,3 i 5,3\%. Respondentów zapytano również o kwotę, jaką są skłonni przeznaczyć na 1 dzień wypoczynku na wsi na osobę. Dominował przedział od 50 do 149 zł ( $83 \%$ wskazań). Do 50 zł na ten cel gotowych było przeznaczyć $13,5 \%$ badanych, a powyżej 150 zł zaledwie $3 \%$.

Badani turyści pochodzili z różnych województw. $Z$ racji lokalizacji terenu badań dominowali mieszkańcy Mazowsza - 61,8\%. 9,8\% turystów przyjechało 


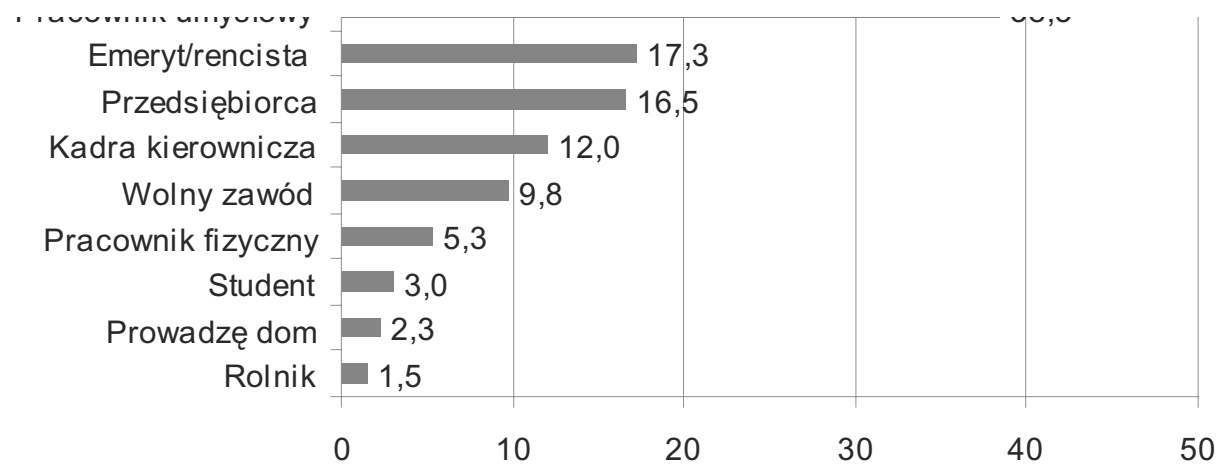

\section{Rysunek 1}

Rodzaj pracy wykonywanej przez badanych turystów [\%]

* Badani mogli wskazać więcej niż jedną odpowiedź.

Źródło: Badania własne.

z województwa dolnośląskiego, 5,7\% z pomorskiego, a po 4,9\% z Podkarpacia oraz Lubelszczyzny. Badani turyści najczęściej mieszkali w mieście - 87,9\%. Większość pochodziła z dużych miast - 46,2\% przyjechało z miast, których liczba mieszkańców przekraczała 200 tys. W 24,2\% przypadków były to miasta między 50 a 200 tys. mieszkańców. Jako środek transportu służący do przybycia do miejsca wypoczynku $88,0 \%$ respondentów wybrało samochód osobowy, $6,0 \%$ pociag, a 3,8\% autobus. 2 osoby przyjechały na rowerach, a jedna motocyklem.

Badani turyści dość często wypoczywali na wsi. Informacje na ten temat zaprezentowano na rysunku 2.

Cztery spośród badanych osób deklarowały wypoczynek na wsi z częstotliwością 20 razy w roku, a po jednej 30 i nawet 50 razy.

Większość badanych $(35,8 \%)$ spędza zazwyczaj na wsi weekend, prawie $1 / 3$ od 3 do 6 dni. Na pobyt tygodniowy decyduje się $6,6 \%$, a dwutygodniowy $4,4 \%$. Troje badanych przyjeżdżało nawet na miesiąc. Osoby przyjeżdzające na dłużej to najczęściej osoby starsze, pobierające świadczenia socjalne. Należy również zauważyć, że częstotliwość wypoczynku na wsi była w większości przypadków odwrotnie proporcjonalna do długości jednorazowego pobytu.

Osobą najczęściej towarzyszącą respondentom podczas wypoczynku był współmałżonek lub partner (54,9\% wskazań). Badani często przyjeżdżali na wieś z całą rodziną $(24,8 \%)$ oraz przyjaciółmi $(21,8 \%)$. Prawie $20 \%$ badanych stanowili dziadkowie/babcie z wnukami, a 4,5\% wypoczywało samotnie. 


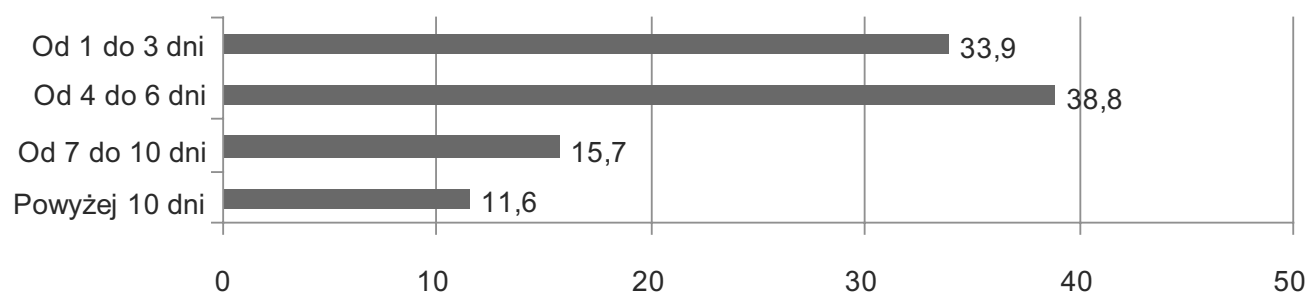

\section{Rysunek 2}

Częstotliwość wypoczynku na wsi przez badanych [\%]

Źródło: Badania własne.

Jednym z celów badań było rozpoznanie powodów, dla których turyści wybrali wieś na miejsce wypoczynku. Najczęściej wskazywane były odpowiedzi dotyczące możliwości wypoczynku w cichym i spokojnym środowisku wiejskim oraz kontakt z przyrodą (rys. 3). Do podobnych wniosków doszli także w swoich badaniach m.in.: Zawadka [2013], Sikorska-Wolak i Zawadka [2012], Balińska i Sikorska-Wolak [2009], Niedziółka i Bogusz [2011].

Mężczyźni zdecydowanie częściej zwracali uwagę na koszty pobytu oraz możliwość spędzenia urlopu w ulubionym krajobrazie, kobiety natomiast doce-

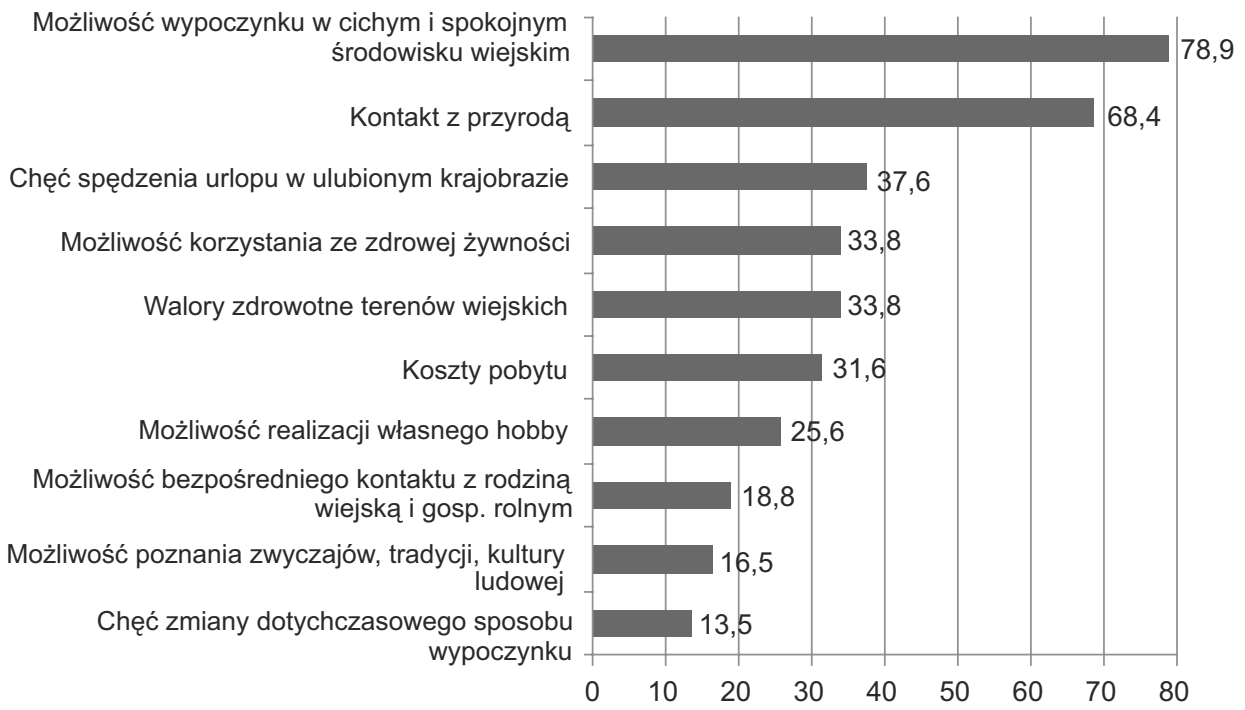

\section{Rysunek 3}

Motywy jakimi kierowali się badani podczas wyboru wsi na miejsce wypoczynku [\%]

* Badani mogli wskazać więcej niż jedną odpowiedź.

Źródło: Badania własne. 
niały możliwość bezpośredniego kontaktu $\mathrm{z}$ rodziną wiejską i gospodarstwem rolnym. Wraz z wiekiem rosło zainteresowanie walorami zdrowotnymi odwiedzanych terenów oraz możliwością korzystania ze zdrowej żywności. Warto w tym miejscu nadmienić, że $66,2 \%$ ogółu badanych chętnie korzystało z posiłków przygotowywanych przez kwaterodawców. Osoby starsze częściej deklarowały ponadto chęć zmiany dotychczasowego sposobu wypoczynku. Ciekawe zależności dostrzec można, analizując motywy wyboru wsi na miejsce wypoczynku w zależności od poziomu wykształcenia badanych (rys. 4). Osoby lepiej wykształcone znacznie częściej doceniały możliwość kontaktu z przyrodą oraz aspekty zdrowotne związane z walorami wsi i żywnością. Wraz ze wzrostem poziomu wykształcenia malało znaczenie kosztów pobytu. Ma to zapewne związek z sytuacją materialną osób gorzej wykształconych.

Respondenci zapytani zostali o powody wyboru gospodarstwa agroturystycznego, w którym wypoczywali. Dominowały wskazania dotyczące standardu obiektu, pozytywnych doświadczeń z poprzedniego pobytu oraz dogodnością dojazdu. Szczegółowe informacje na ten temat zaprezentowano na rysunku 5.

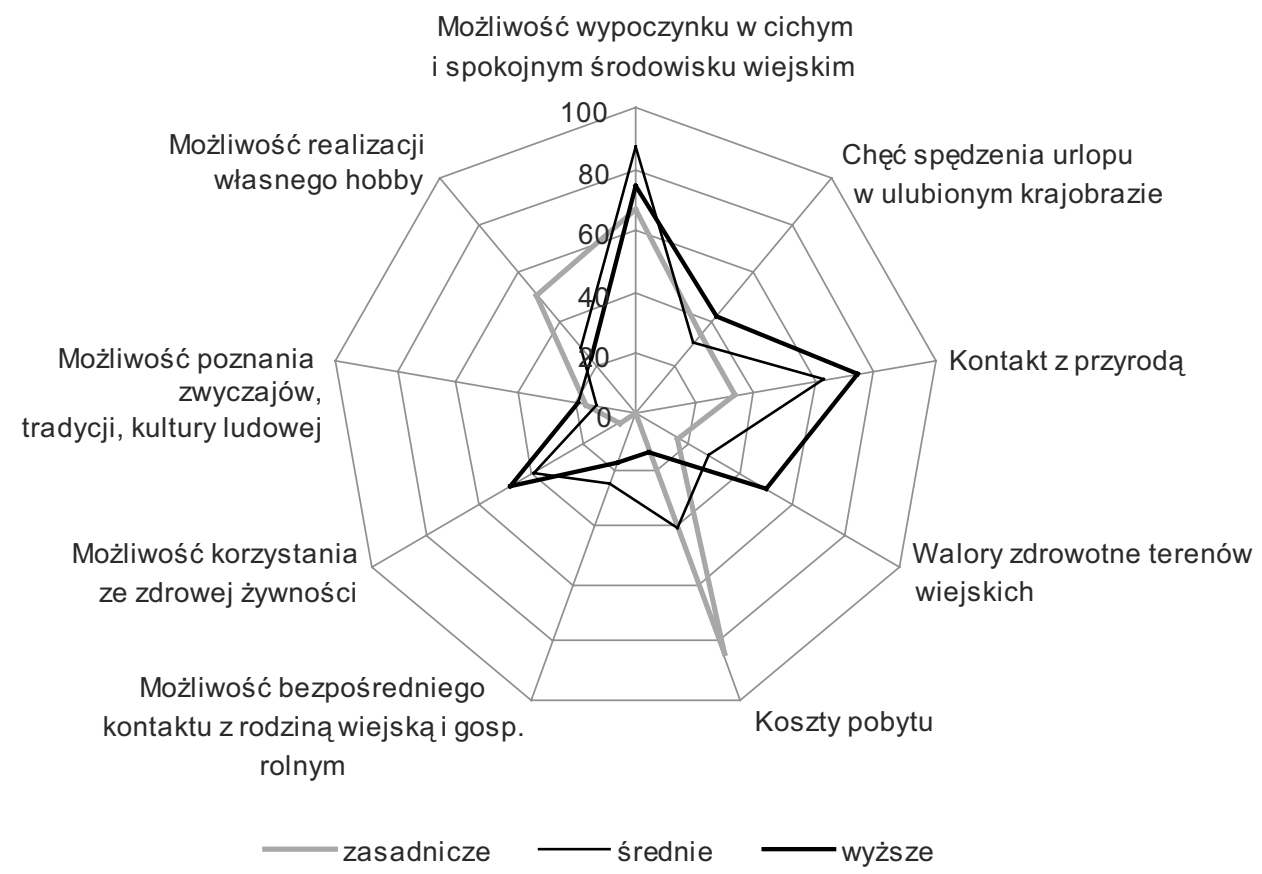

\section{Rysunek 4}

Motywy wyboru wsi na miejsce wypoczynku w zależności od poziomu wykształcenia badanych [\%]

Źródło: Badania własne. 


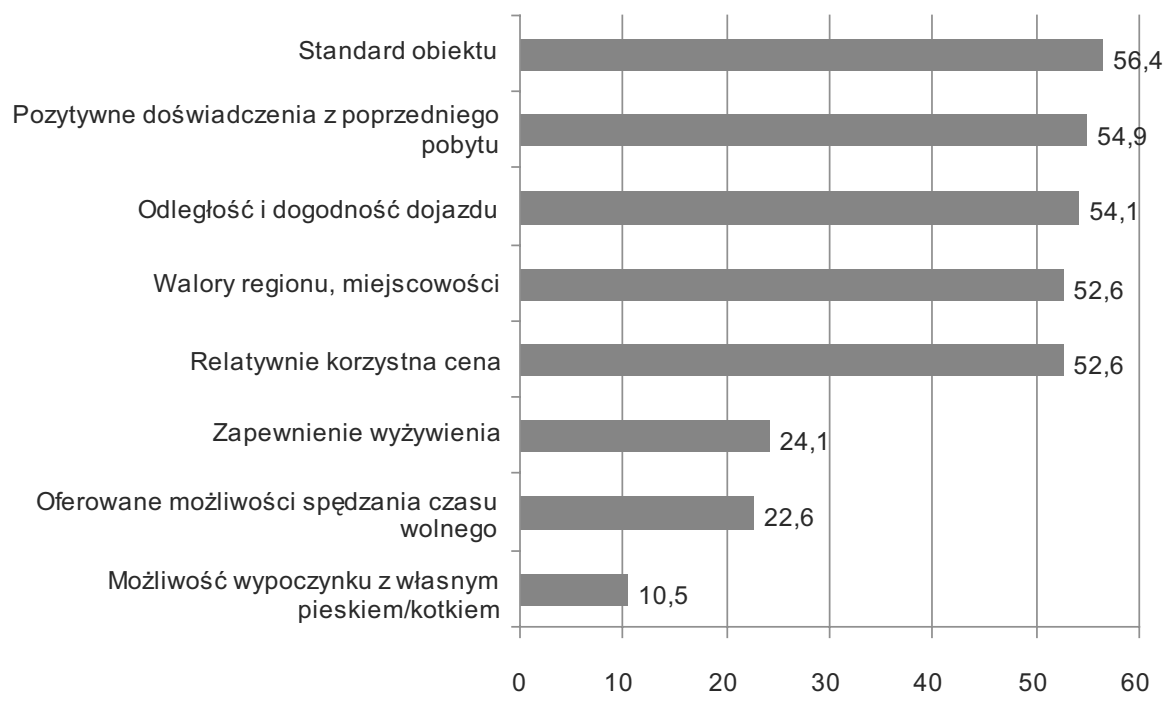

\section{Rysunek 5}

Powody wyboru przez badanych konkretnego gospodarstwa agroturystycznego [\%]

* Badani mogli wskazać więcej niż jedną odpowiedź.

Źródło: Badania własne.

Mężczyźni nieznacznie częściej wskazywali standard obiektu, walory regionu i miejscowości oraz (podobnie jak osoby młode) korzystną cenę. Osoby starsze bardzo dużą wagę przywiązywały do możliwości wyżywienia oraz (podobnie jak osoby lepiej wykształcone) do standardu obiektu. Ta grupa respondentów częściej wybierała obiekty, do których zabrać mogli własnego zwierzaka.

Dla zdecydowanej większości badanych źródłem, z którego pozyskali informacje dotyczące miejsca wypoczynku był Internet (60,9\%). Wniosek ten potwierdzają również inne badania autora [2010], a także badania m.in. Krzyżanowskiej i Wojtkowskiego [2012], Stepaniuka [2010], Kolczatka i Jankowskiego [2006], Niedziółki [2008] czy Prochorowicz [2006]. Stosunkowo dużą grupę stanowiły również osoby bazujące na opiniach i rekomendacjach rodziny i znajomych (39,1\%). Sporadycznie wskazywane były ponadto targi turystyczne czy ulotki, foldery i katalogi. Warto tu zauważyć, że osoby starsze częściej bazowały na opiniach rodziny lub znajomych.

Dla wielu turystów pobyt na wsi to świetna okazja do aktywnego wypoczynku. Na rysunku 6 zaprezentowano preferowane przez respondentów jego formy. Największą popularnością cieszyły się wycieczki piesze oraz rowerowe. Powodem rzadszego wskazywania kąpieli i gier zespołowych może być fakt niewystarczającej infrastruktury w tym zakresie. 


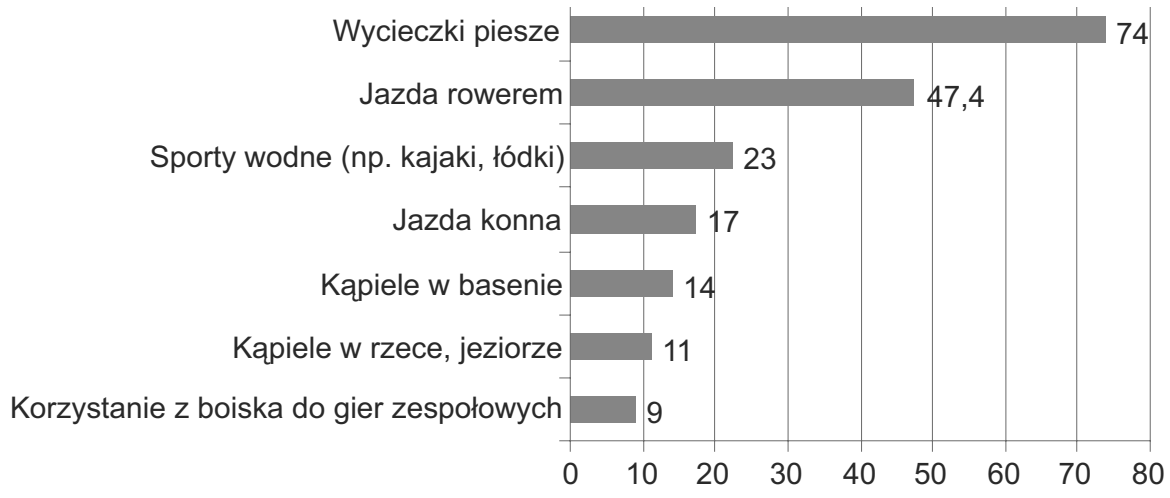

\section{Rysunek 6}

Formy aktywnego wypoczynku wybierane przez badanych podczas pobytu na wsi [\%]

*Badani mogli wskazać więcej niż jedną odpowiedź.

Źródło: badania własne.

Wycieczki piesze, jako najmniej wymagająca forma ruchy, najczęściej wybierane były przez osoby starsze. Ta grupa badanych, będąc na wsi chętnie uprawiała także nordic walking. Sporty wodne oraz jazdę konną wskazywały znacznie częściej osoby lepiej wykształcone (co powiązane było z lepszą oceną własnej sytuacji materialnej). Powodu mniejszego zainteresowania tymi formami rekreacji wśród osób gorzej sytuowanych finansowo doszukiwać się można w konieczności najczęściej odpłatnego wypożyczenia odpowiedniego sprzętu i konia pod siodło.

Respondenci zapytani zostali także o atrakcje $\mathrm{z}$ jakich dodatkowo chcieliby skorzystać. Znaczna część badanych zainteresowana była szeroko pojętą sferą kulturową odwiedzanych terenów, w tym tradycjami kulinarnymi (rys. 7).

Szczególne zainteresowanie pokazami tradycji i folkloru lokalnego, spotkaniami z artystami oraz degustacją regionalnej kuchni przejawiały osoby starsze, a także młode (do 30. roku życia). Ci ostatni chętnie skorzystaliby również $\mathrm{z}$ wellness i SPA. Osoby w średnim wieku (podobnie jak lepiej wykształcona część respondentów) zdecydowanie częściej wskazywały odpowiedzi dotyczące krajoznawczych wycieczek po okolicy, a także przejażdżek bryczką i kuligów. Grupa ta przejawiała ponadto większe zainteresowania warsztatami rękodzieła ludowego i festynami, dożynkami oraz jarmarkami.

Respondenci poproszeni zostali o opinie dotyczące możliwości poprawienia jakości usług świadczonych przez właścicieli gospodarstw agroturystycznych. Najwięcej uwag (po ok. 30\%) związanych było z niedostatkiem sprzętu 


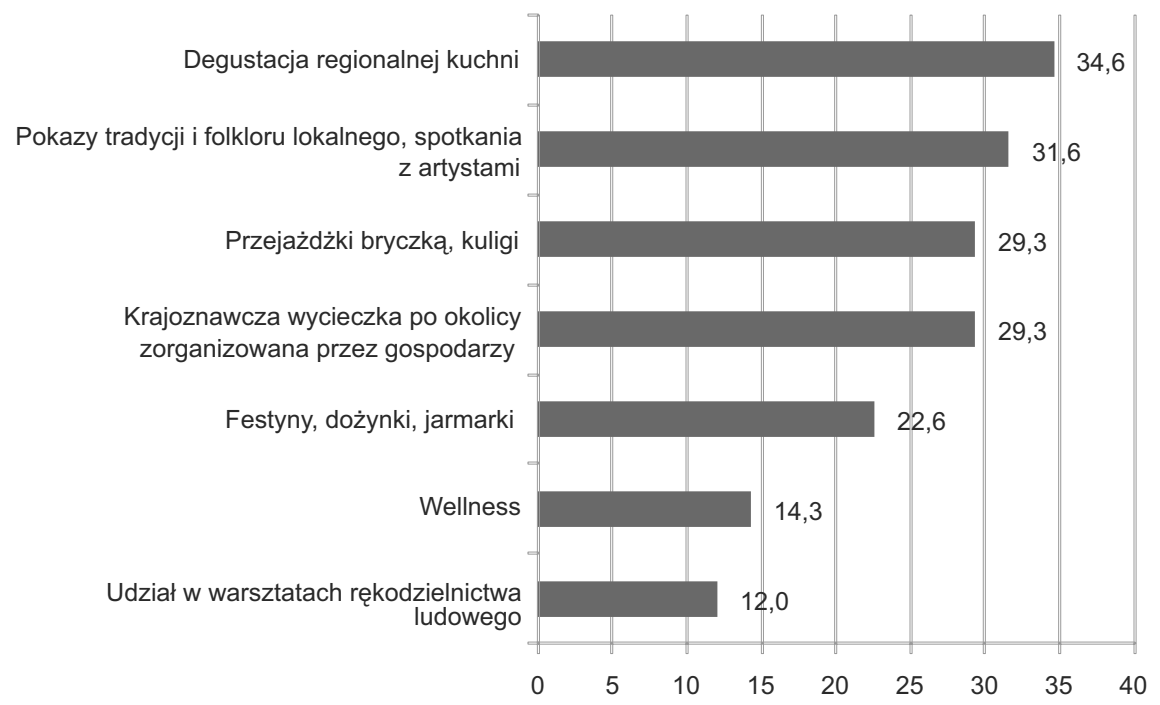

\section{Rysunek 7}

Atrakcje, z jakich podczas wypoczynku na wsi dodatkowo chcieliby skorzystać respondenci $[\%]^{*}$

*Badani mogli wskazać więcej niż jedną odpowiedź.

Źródło: badania własne.

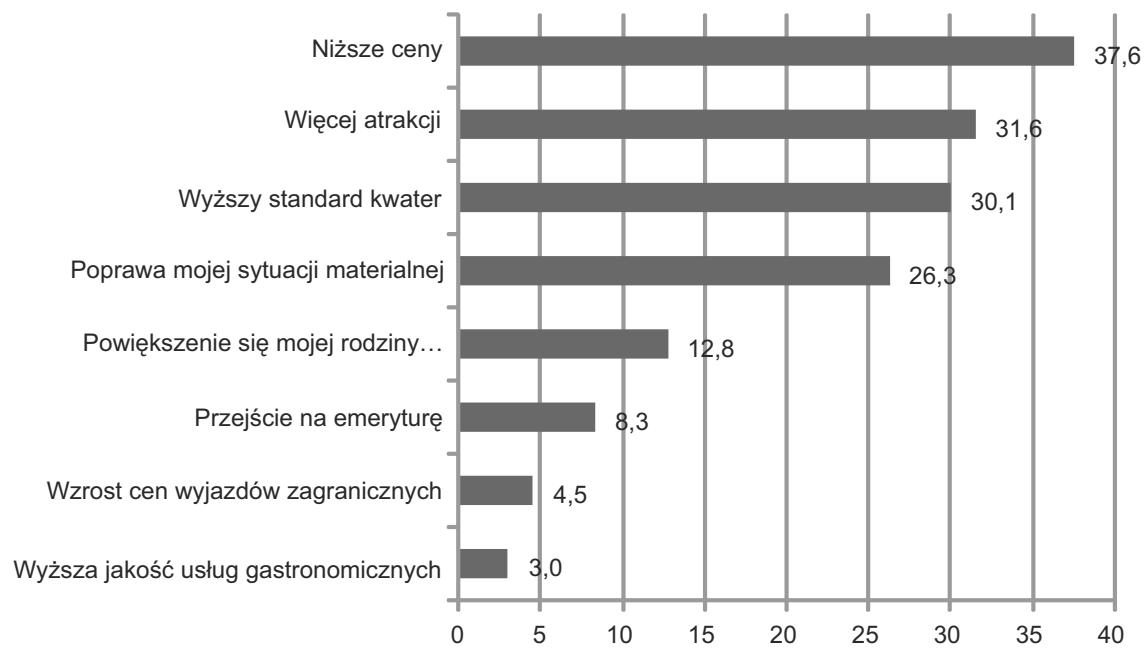

\section{Rysunek 8}

Determinanty zwiększenia częstotliwości wypoczynku na wsi w opinii badanych [\%]

*Badani mogli wskazać więcej niż jedną odpowiedź.

Źródło: Badania własne. 
rekreacyjno-sportowego oraz brakami w estetyce urządzeń sanitarnych. Wypoczywający dostrzegali ponadto niedostateczne wyposażenie pokoju sypialnego oraz mało komfortowe miejsce do spania (1/4 badanych). Po około $14 \%$ badanych wskazywało na konieczność wzbogacenia i urozmaicenia oferty dotyczącej organizacji czasu wolnego w gospodarstwie, a także ograniczenia liczby gości w obiekcie. Pojawiały się także uwagi dotyczące znikomej wiedzy gospodarzy na temat okolicznych walorów i atrakcji turystycznych.

Mimo świadomości pewnych „niedociagnięć” oraz ograniczeń związanych z wypoczynkiem na wsi, 59,4\% badanych deklarowało podobną częstotliwość takiego sposobu spędzania czasu wolnego w przyszłości, a 21,5\% miało zamiar odwiedzać wieś częściej. W celu dokładniejszej analizy tej sytuacji badani zapytani zostali o to, co mogłoby zachęcić ich do częstszego wypoczynku w gospodarstwach agroturystycznych (rys. 8).

Wśród odpowiedzi dominowały wskazania dotyczące kwestii finansowych $(68,4 \%)$ oraz zwiększenia liczby atrakcji turystycznych $(31,6 \%)$. Osoby lepiej wykształcone najczęściej wskazywały odpowiedzi związane z poprawą standardu obiektów noclegowych oraz jakością usług gastronomicznych.

\section{Wnioski}

Wypoczynek w gospodarstwach agroturystycznych preferowany był głównie przez dobrze wykształconych mieszkańców dużych miast w średnim wieku. Stosunkowo dobrze oceniali oni własną sytuację materialną.

Turyści przyjeżdżali na wieś głównie samochodami osobowymi. Oznacza to ich mobilność i fakt, że mieli możliwość skorzystania z różnego rodzaju atrakcji, nie tylko w bezpośrednim otoczeniu miejsca pobytu, ale także w jego bliższej lub dalszej okolicy. Turysta musi jednak mieć świadomość istnienia takich miejsc - dobrze byłoby, gdyby mógł zdobyć informacje na ten temat w samym obiekcie noclegowym.

Główny źródłem informacji podczas wyboru obiektu był dla badanych Internet. Dużą rolę przypisać należy także tzw. poczcie pantoflowej, czyli marketingowi szeptanemu, gdzie źródłem informacji na temat obiektów turystyki wiejskiej byli krewni lub znajomi. Pozostałe formy promocji (a szczególnie te związane z koniecznością poniesienia znacznych nakładów finansowych - udział $\mathrm{w}$ targach turystycznych, foldery i ulotki reklamowe czy reklama w prasie, radio i telewizji) były wykorzystywane przez turystów sporadycznie.

Cisza i spokój oraz kontakt z przyrodą to najczęściej wskazywane motywy wyboru wsi na miejsce wypoczynku. Przy wyborze konkretnego obiektu duże znaczenie miał natomiast standard obiektu, łatwość dojazdu, a także walory re- 


\section{2}

gionu i miejscowości. Bardzo istotne były również doświadczenia z poprzedniego pobytu.

Wśród form aktywności fizycznej podejmowanej przez badanych podczas wypoczynku na wsi preferowane były te, które nie powodują nadmiernego obciążenia - m.in. wycieczki piesze oraz rowerowe. Atrakcje, z których badani dodatkowo chcieliby skorzystać podczas wypoczynku, związane były w dużej mierze ze sferą kulturową wsi. Duża liczba wskazań dotyczyła także aktywności krajoznawczej badanych.

Zaprezentowane treści to jedynie przyczynek do szerszych badań autora dotyczących preferencji i zachowań osób wypoczywających na wsi. Ich rozpoznanie i wskazanie umożliwi wiejskim usługodawcom odpowiednie skomponowanie oferty wypoczynkowej, a także jej specjalizację, mającą na celu maksymalne zaspokojenie potrzeb związanych z pobytem i wypoczynkiem na wsi poprzez optymalne dopasowanie zakresu oferty oraz jakości świadczonych usług do konkretnego segmentu turystów. Zasadne wydaje się więc podjęcie szerszych i bardziej szczegółowych badań na ten temat.

\section{Literatura}

BALIŃSKA A., SIKORSKA-WOLAK I., 2009: Turystyka wiejska szansq rozwoju wschodnich terenów przygranicznych na przykładzie wybranych gmin, Wydawnictwo SGGW, Warszawa.

KŁODZIŃSKI M., 1999: Aktywizacja gospodarcza obszarów wiejskich, IRWiR PAN, Centrum Naukowo-Wdrożeniowe SGGW, Warszawa.

KŁODZIŃSKI M., RZECZKOWSKA M., 2000: Rozwój przedsiębiorczości wiejskiej w krajach Unii Europejskiej-wskazówki dla Polski, [w:] Rozwój przedsiębiorczości wiejskiej $w$ warunkach integracji z Uniq Europejska, PAN, Akademia Rolnicza w Szczecinie, Warszawa.

KOLCZATEK R., JANKOWSKI K., 2006: Internet - nowoczesne źródło informacji i reklamy $w$ agroturystyce, [w:] Marketing $w$ agroturystyce, (red.) M. Plichta, J. Sosnowski, Wydawnictwo Akademii Podlaskiej, Siedlce.

KRZYŻANOWSKA K., WOJTKOWSKI R., 2012: Rola internetu w promocji ustug agroturystycznych, Studia Ekonomiczne i Regionalne 5(1).

NIEDZIÓŁKA A., 2008: Wykorzystanie sieci Internet w promocji produktu agroturystycznego na przykładzie województwa małopolskiego, [w:] Zastosowanie technologii informacyjnych do wspomagania zarzadzania procesami gospodarczymi, (red.) N. Semeniuk, R. Mosdorf, Wydawnictwo Wyższej Szkoły Finansów i Zarządzania w Białymstoku, Białystok.

NIEDZIÓŁKA A., BOGUSZ M., 2011: Uwarunkowania rozwoju turystyki społecznej na przyktadzie gminy Istebna, Folia Pomeranae Universitatis Technologiae Stetinensis, Oeconomica 288(64), s. 133-141. 
PROCHOROWICZ M. 2006: Zastosowanie reklamy elektronicznej w promocji gospodarstw agroturystycznych, [w:] Marketing $w$ agroturystyce, (red.) M. Plichta, J. Sosnowski, Wydawnictwo Akademii Podlaskiej, Siedlce.

SIKORSKA-WOLAK I., ZAWADKA J., 2012: Oczekiwania konsumentów na rynku ustug agroturystycznych, Studia Ekonomiczne i Regionalne 5 (1), s. 34-47.

STEPANIUK K., 2010: Wybrane koncepcje zwiazane z projektowaniem, wdrożeniem i rozwojem działalności e-agroturystycznej na przykładzie województwa podlaskiego, Acta Scientiarum Polonorum. Oeconomia 9(4).

ZAWADKA J., 2010: Ekonomiczno-spoteczne determinanty rozwoju agroturystyki na Lubelszczyźnie (na przykładzie wybranych gmin wiejskich), Wydawnictwo SGGW, Warszawa.

ZAWADKA J., 2013: Zachowania turystów wypoczywajacych na wsi i czynniki je warunkujace, [w:] Budowanie konkurencyjności obszarów wiejskich, (red.) K. Krzyżanowska, Wydawnictwo SGGW, Warszawa.

\title{
Preferences and behavior of tourists vacationing in agritourist farms in the surroundings of Kampinos National Park
}

\begin{abstract}
The article presents the results of research on the preferences and behaviors of people vacationing in the countryside. Surveys were conducted during the summer 2013 years among 133 tourists vacationing in agritourist farms in the surroundings of Kampinos National Park. The paper presents the characteristics and behavior of an average tourist visitor in rural areas. The reasons for choosing this form of tourism were analysed, as well as the choice of a specific offer. Moreover, the study covered sources of information about the object used by tourists, preferred ways of spending free time and expectations of diversifying and improving the offer. Finally, the determinants of behavior and expectations of tourists, such as age, education level and financial situation of the respondents was analysed.
\end{abstract}


